Scientific article

Volumen 33(1): Artículo 45633, 2022

e-ISSN 2215-3608, doi:10.15517/am.v33i1.45633

https://revistas.ucr.ac.cr/index.php/agromeso/index

\title{
Transplanting and the addition of boron in sweet corn (Zea mays L. group saccharate) production ${ }^{1}$
}

\section{Trasplante y adición de boro en la producción de maíz dulce (Zea mays L. grupo saccharate)}

\author{
Aziz Mahdi Abd Al-Shammari², Ghassan Jaafar Hamdi ${ }^{2}$, Solieman Daowd Najm Abdullah ${ }^{2}$
}

\begin{abstract}
Reception: February $2^{\text {nd }}, 2021$. Acceptance: July $30^{\text {th }}, 2021$. This work was part of a master's thesis in the effect of the method of cultivation and foliar fertilization with boron on the growth and yield of three crosses of sweet corn in the spring season. There is no financial support for the research, all costs were covered by the researcher.

2 University of Diyala, College of Agriculture, Department of Horticulture and Landscape Gardening, Baqubah, Iraq. Dr.azez@agriculture. uodiyala.edu.iq (https://orcid.org/0000-0003-4489-9620), ghassanhamdi38@ gmail.com (corresponding author; https://orcid.org/0000-00019312-8238), soliemanabdullah211@gmail.com (https://orcid.org/0000-0002-1402-8798).
\end{abstract}

\begin{abstract}
Introduction. Low seedbed temperatures at the planting and the direct sowing method can reduce the sweet corn germination. Transplanting may offer optimum environmental conditions for seed germination, early crop maturity, and increase sweet corn (Zea mays L. group saccharata) productivity. Boron deficiency depresses sweet corn yield through male sterility. Objective. To evaluate the effect of transplanting and the addition of boron in sweet corn production. Materials and methods. A field experiment was conducted from March 19 to June 20, 2020 at the Research Station of Horticulture Department and Landscape Gardening Architecture, University of Diyala, Baqubah, Iraq. Direct sowing and transplanting, and foliar application of boron at 0,50 , or $75 \mathrm{mg} \mathrm{L}^{-1}$ was evaluated to determine effects on the yield, the yield components, and water use efficiency of sweet corn cultivars: Roi Soleal, Seker misir, and Succar. Results. The cv. Seker Misir matured faster (57.5 days), had wider ears $(4.53 \mathrm{~cm})$, more kernel rows (16.0), the highest kernel yield $\left(6.00 \mathrm{t} \mathrm{ha}^{-1}\right)$, and a higher water use efficiency (WUE) $\left(2.85 \mathrm{~kg} \mathrm{~m}^{-3}\right)$. The cv. Succar had the longest ears $(18.48 \mathrm{~cm})$ and the heaviest fresh ears $(251 \mathrm{~g})$. Transplanting hastened the time to maturity $(54.18$ days), and produced the longest ears $(17.91 \mathrm{~cm})$, widest ears $(4.52 \mathrm{~cm})$, most kernel rows $(15.96)$, heaviest fresh ears $(229 \mathrm{~g})$, the highest kernel yield $\left(5.56 \mathrm{t} \mathrm{ha}^{-1}\right)$, and the highest WUE $\left(2.64 \mathrm{~kg} \mathrm{~m}^{-3}\right)$. The $50 \mathrm{mg} \mathrm{L}^{-1}$ fertilizer treatment produced the longest ears $(17.61 \mathrm{~cm})$, widest ears $(4.58 \mathrm{~cm})$, more kernel rows $(16.61)$, the highest kernel yield $(5.64$ $\left.\mathrm{t} \mathrm{ha}{ }^{-1}\right)$, and the highest WUE $\left(2.68 \mathrm{~kg} \mathrm{~m}^{-3}\right)$. The least time to maturity $(57.72$ days) and heaviest fresh ears $(232 \mathrm{~g})$ occurred with $75 \mathrm{mg} \mathrm{L}^{-1}$ of boron fertilizer. Conclusion. The use of $50 \mathrm{mg} \mathrm{L}^{-1}$ boron, as a foliar fertilizer, appears to be, next to the transplanting method, suitable for the cultivation of sweet corn plants to increase productivity and WUE.
\end{abstract}

Keywords: cultivation method, direct sowing, fertilization, grain yield.

\section{Resumen}

Introducción.Las bajas temperaturas del semillero en la plantación y el método de siembra directa pueden reducir la germinación del maíz dulce. El trasplante puede ofrecer condiciones ambientales óptimas para la germinación de 
la semilla, una madurez temprana del cultivo y un aumento de la productividad del maíz dulce (Zea mays L. grupo saccharata). La deficiencia de boro reduce su rendimiento por la esterilidad masculina. Objetivo. Evaluar el impacto de los métodos de siembra y la aplicación de boro en cultivares de maíz dulce. Materiales y métodos. Se realizó un experimento de campo del 19 de marzo al 20 de junio de 2020 en la Estación de Investigación del Departamento de Horticultura y Arquitectura de Jardinería Paisajista de la Universidad de Diyala, Baqubah, Irak. Se evaluó la siembra directa y el trasplante, y la aplicación foliar de boro a 0,50 o $75 \mathrm{mg} \mathrm{L}^{-1}$, para determinar los efectos en el rendimiento, los componentes del rendimiento y la eficiencia en el uso del agua de los cultivares de maíz: dulce Roi Soleal, Seker misir y Succar. Resultados. El cv. Seker Misir maduró más rápido (57,5 días), tuvo mazorcas más anchas (4,53 cm), más hileras de granos $(16,0)$, el mayor rendimiento de granos $\left(6,00 \mathrm{t} \mathrm{ha}^{-1}\right)$ y una mayor eficiencia en el uso del agua (WUE) $\left(2,85 \mathrm{~kg} \mathrm{~m}^{-3}\right)$. El cv. Succar mostró las mazorcas más largas $(18,48 \mathrm{~cm})$ y las mazorcas frescas más pesadas (251 g). El trasplante aceleró el tiempo hasta la madurez (54,18 días) y produjo las mazorcas más largas $(17,91 \mathrm{~cm})$, las más anchas $(4,52 \mathrm{~cm})$, la mayoría de las hileras de granos $(15,96)$, las mazorcas más pesadas $(229 \mathrm{~g})$, el mayor rendimiento de granos $\left(5,56 \mathrm{t} \mathrm{ha}^{-1}\right)$ y una mayor WUE $\left(2,64 \mathrm{~kg} \mathrm{~m}^{-3}\right)$. El tratamiento con $50 \mathrm{mg} \mathrm{L}^{-1}$ de fertilizante produjo las espigas más largas $(17,61 \mathrm{~cm})$, las espigas más anchas $(4,58 \mathrm{~cm})$, más hileras de granos $(16,61)$, el mayor rendimiento de granos $\left(5,64 \mathrm{t} \mathrm{ha}^{-1}\right)$ y el WUE más alto $\left(2,68 \mathrm{~kg} \mathrm{~m}^{-3}\right)$. El menor tiempo hasta la madurez (57,72 días) y las espigas frescas más pesadas $\left(232 \mathrm{~g}\right.$ ) se produjeron con $75 \mathrm{mg} \mathrm{L}^{-1}$ de fertilizante de boro. Conclusión. El uso de $50 \mathrm{mg} \mathrm{L}^{-1}$ boro, como fertilizante foliar, parece ser, junto con el método de trasplante, adecuado para el cultivo de plantas de maíz dulce para aumentar la productividad y el WUE.

Palabras clave: método de cultivo, siembra directa, fertilización, rendimiento de grano.

\section{Introduction}

Sweet corn (Zea mays L. group saccharata) is a special type of corn that exhibits homozygosis mutant recessive alleles. These recessive mutant alleles contribute to a loss of the pathway through which basic carbohydrates (sucrose) are transformed into complex ones (starch) in the endosperm (Tracy, 2001) and green corn kernels are softer and sweeter due to low starch levels.

Genotype strongly impacts the nature of growth and productivity (Srdić et al., 2016). Sweet corn is conventionally grown by direct sowing, but research has shown that transplanting results in higher agricultural and economic efficiency methods (Fanadzo et al., 2009; Grubinger, 2014). The benefits of transplanting are more uniform fields, greater control of crop population, compensation for a period of growth too short for a full crop cycle, good sowing time, more effective use of the hybrid seed, good weed and water management, early crop maturity and higher yield resulting in higher market prices (Sánchez-Andonova et al., 2014; Welbaum et al., 2001).

Environmental conditions, particularly temperature, influence productivity for sweet corn (Dale \& Drennan, 1997). To produce seedlings for transplanting seeds are sown under protected conditions which improve germination; poor germination is a problem in cold soils. In the greenhouse, germination contributes to reduced crop length, early flowering in the field, economies in seed rate, and time saved. Ecological considerations and defense against pests are controlled with direct sowing (Céccoli et al., 2014; Wang et al., 2012).

Transplanting improved plant survival, avoid of soilborne diseases (Dale \& Drennan, 1997). Plants cultivated with transplanting develop better both vegetatively and generatively (Ugur \& Maden, 2015), which might be reflected in the final performance in yield attributes and total yield for sweet corn (Fayaz et al., 2019; SánchezAndonova et al., 2014; Tampus \& Escasinas, 2019).

Boron is an important nutrient for the growth and development of plants and participates in several physiological processes in plants. Boron contributes to cell wall strength and development, as well as being critical to cell division, seed development, sugar synthesis and transport, respiration, and hormone development (Camacho- 
Cristóbal et al., 2008; Fagan et al., 2016; Zoz et al., 2016). This element also regulates the production of auxin in the plants, wich is a plant hormone that among other functions is responsible for elongation, cell division, and growth of the plant (Mengel et al., 2001). Boron is essential to pollen kernel germination and pollen tube elongation (Krichevsky et al., 2007), which helps provide successful fertilization or pollination, preventing the abortion of flowers, and improves the grain setting by improving the grain filling process and reducing the male sterility often observed in boron deficient condition (Abdel-Motagally \& El-Zohri, 2018).

Boron is involved in carbohydrates metabolism and essentially necessary for protein synthesis, nitrogen fixation and boron increased the levels of photosynthetic pigments (Günes et al., 2011; Lordkaew et al., 2011). Boron deficiency leads to the deficiency of other essential nutrients by affecting their rate of absorption and use (Camacho-Cristóbal et al., 2008). Therefore, the adequate supply of boron is very important for the growth and development of plants.

Boron is a significant micronutrient needed for normal plant development and growth (Kaur \& Nelson, 2015). It is involved in many plant processes, such as sugar transport, cell wall synthesis, lignification, meristematic tissue cell division, development of petal and leaf buds, integrity of cell wall structure, sugar and hydrocarbon metabolism and transport, metabolism of ribose nucleic acid (RNA), respiration, metabolism of indole acetic acid (IAA), production and transition of cytokinin, phenol metabolism, metabolism of nitrogen (Ahmad et al., 2014; Gupta, 1993; Marschner \& Rimmington, 1996; Pilbeam \& Kirkby, 1983). A successful way to fix micronutrient shortages may be foliar nutrient sprays, which often contribute to better yields and crop quality.

The objective of this study was to evaluate effect of transplanting and the addition of boron in sweet corn production.

\section{Materials and methods}

A field experiment was conducted from March 19 to June 20, 2020 at the Research Station of Horticulture Department and Landscape Gardening Architecture, University of Diyala, Baqubah, Iraq (latitude 3341'17.26" $\mathrm{N}$, longitude $44^{\circ} 35^{\prime} 36.08^{\prime \prime} \mathrm{E}$, altitude $31 \mathrm{~m}$ ). The region has a semiarid climate. The annual mean temperature and precipitation are $28.2{ }^{\circ} \mathrm{C}$ and $200 \mathrm{~mm}$, located close to the field trials. The experiment was arranged in a split-split plot in a completely randomized design with the sweet corn cvs. Roi Soleal, Seker misir, and Succar as the main plot, and the planting methods direct sowing and transplanting as the subplot. Transplanting and direct sowing were done at the same time. Foliar application of doses 0,50 , and $75 \mathrm{mg} \mathrm{L}^{-1}$ was the sub-sub plot with four replications. Each experimental unit was $5 \mathrm{~m}$ length and $0.75 \mathrm{~m}$ width; area of the experimental unit was 3.75 $\mathrm{m}^{2}$, with 6 rows planting. Experimental units were separated by $1.0 \mathrm{~m}$ to avoid interference of fertilizer in adjacent treatment. Spacing was $0.75 \mathrm{~m}$ between rows and $0.25 \mathrm{~m}$ between plants, each experimental unit contained 20 plants, corresponding to a planting density of 53,333 plants ha- ${ }^{-1}$. In direct sowing, the seed was soaked in water (irrigation water) for $24 \mathrm{~h}$ to break dormancy and to standardize germination and hand sown at $5 \mathrm{~cm}$ with $3 \mathrm{seed} /$ hole on 19 March 2020 and irrigated 3-times with $400 \mathrm{~mL}$ for germination. Seedlings were transplanted at the 3-5 leaf stage, to withstand against adverse effects of wind and frost. Later, when plants had three true leaves, plants were thinned to 1 seeding/hole. For the transplanting method, the seed was sown in plastic trays, $0.50 \times 1 \mathrm{~m}$, with 104-cells/tray, containing peat moss as a medium on 19 February 2020, in a greenhouse, and seedlings were ready to transplant when they had 3-5 true leaves on 19 March 2020. Before planting, soil samples were collected at a 0-30 $\mathrm{cm}$ depth, air-dried, passed through a $2 \mathrm{~mm}$ sieve, and used for the determination of physical and chemical soil characteristics according to Black (1965).

The soil used in this study was silty-loam with moderately acidic with a $\mathrm{pH}$ of 7.04 and $\mathrm{EC}_{1: 1}\left(7.55 \mathrm{dS} \mathrm{m}^{-1}\right)$, which is suitable for sweet corn production. Organic matter was low as represented by organic carbon of $6.9 \mathrm{~g} \mathrm{~kg}^{-1}$. 
It has medium total $\mathrm{N}\left(54.01 \mathrm{mg} \mathrm{kg}^{-1}\right)$, very low in available $\mathrm{P}\left(8.04 \mathrm{mg} \mathrm{kg}^{-1}\right)$ and low in exchangeable $\mathrm{K}(81.78$ $\left.\mathrm{mg} \mathrm{kg}{ }^{-1}\right), \mathrm{CaCo}_{3}\left(260.1 \mathrm{~g} \mathrm{~kg}^{-1}\right)$, field capacity $(25 \%)$, and bulk density $\left(1.35 \mathrm{~g} \mathrm{~cm}^{-3}\right)$.

A total of $8 \mathrm{Mt} \mathrm{ha}^{-1}$ poultry litter was added to the soil during bed preparation. The silty-loam soil was prepared by plowing and formed into raised beds. The Irrigation was applied to each plot via pipe a surface drip irrigation T-Tape (Bow smith, Inc., Exeter, CA) with a wall thickness of $1 \mathrm{~mm}$, and a distance between emitters of $11 \mathrm{~cm}$ between emitters and measured by the digital water flow meter. The maximum water flow rate of the emitters was $11 \mathrm{~h}^{-1}$. Plants were irrigated to reach field capacity when depletion of $50 \%$ of available water occurred.

A soluble $20 \mathrm{~N}-20 \mathrm{P}-20 \mathrm{~K}$ fertilizer was added in four split applications throughout the growth period at $100 \mathrm{~kg}$ ha $^{-1}$ with the irrigation water. The sources of nitrogen, phosphorus, and potassium were $\mathrm{NH}_{4} \mathrm{NO}_{3}, \mathrm{P}_{2} \mathrm{O}_{5}$, and $\mathrm{K}_{2} \mathrm{SO}_{4}$, respectively.

Boron as water-solubor $\left(\mathrm{Na}_{2} \mathrm{~B}_{8} \mathrm{O}_{13}{ }_{4} \mathrm{H}_{2} \mathrm{O}\right.$; Villa de Madrid 14. Pol. Ind. Fuente del Jarro, 46988 PATERNA, Valencia, Spain), containing $13.3 \% \mathrm{~B}$, was applied with a backpack sprayer at three concentrations $(0,50$, or 75 $\mathrm{mg} \mathrm{L}^{-1}$ ) three times, at a 10-day interval, starting at flowering (Starting from 4/19/2020). All foliar applications were performed in the early morning. Weeds were controlled manually.

\section{Data gathered}

Characteristics evaluated were: meantime to harvest (Early of maturity) (day), the maturity date was determined when the ears were large enough to fill the husk tightly to the top, and when the kernels were just beginning the milk stage. Ear characteristics such as ear length $(\mathrm{cm})$, ear diameter $(\mathrm{cm})$, and its number of kernel rows were recorded, and ears fresh weight $(\mathrm{g})$, were determined from the mean of 18 randomly selected ears per plot per treatment. total ears productivity $\left(\mathrm{t} \mathrm{ha}^{-1}\right)$ all cobs from the harvestable area of each treatment plot were harvested, husked, and weighed to obtain the total yield; grain productivity $\left(\mathrm{t} \mathrm{ha}^{-1}\right)$ was recorded values of water use efficiency $\left(\mathrm{kg} \mathrm{m}^{-3}\right)$ were calculated for different treatments after harvest according to the following equation (1):

Water use efficiency $($ WUE $)=$ total yield $/$ water applied

\section{Data Analysis}

At harvest, data were subjected to analysis of variance (F-Test) in SAS (ver. 9.1, SAS, Inc., Cary, NC). When there was a significant effect, the Tukey test (5\%) were applied for the Mo application periods, using the Agro Estat software (Barbosa \& Maldonado, 2015).

\section{Results}

For all measured variables, interactions took precedence over the main effects (Table 1).

Results in Table 2 showed the effect of cultivars on all measured traits. The cv. Seker Misir had less time to maturity, wider ears, a greater number of kernel rows, most kernel yield, and higher WUE. The cv. Succar had the tallest ears and heaviest fresh ears, while the 'Roi Soleal' cultivar had the least.

In this study, the transplanting method produced less time to maturity, tallest ears, widest ears, a greater number of kernel rows, heaviest fresh ears, most kernel yield, and higher WUE, while the direct sowing method had the least (Table 2).

Application of boron fertilizer at $50 \mathrm{mg} \mathrm{L}^{-1}$ produced tallest ears, widest ears, a greater number of kernel rows, most kernel yield, and highest WUE (Table 2), also produced the less time to maturity and ear heaviest with the foliar boron at $75 \mathrm{mg} \mathrm{L}^{-1}$, while the plants not treated with boron fertilizer had the least. 
Table 1. Analysis of variance for the main impacts of tree sweet corn (Zea mays) cultivars, establishment methods, three boron doses, and their interactions on time to maturity, length and diameter of ears, kernel rows number, ears fresh weight, grain products, and WUE in sweet corn. Research Station of Horticulture Department and Landscape Gardening Architecture, University of Diyala, Baqubah, Iraq, from 19 March to June 2020.

Cuadro 1. Análisis de varianza para los principales efectos de tres cultivares de maíz dulce (Zea mays), método de establecimiento, y trasplante, tres dosis de boro y sus interacciones, sobre el tiempo de maduración, la longitud y el diámetro de las mazorcas, el número de filas de granos de las mazorcas peso fresco, los productos de grano y el uso del agua (WUE) en el maíz dulce. Research Station of Horticulture Department and Landscape Architecture, University of Diyala, Baqubah, Iraq, 19 de marzo al 20 de junio de 2020.

\begin{tabular}{|c|c|c|c|c|c|c|c|c|}
\hline Source of variation & df & $\begin{array}{l}\text { Early of } \\
\text { maturity }\end{array}$ & $\begin{array}{c}\text { Ear } \\
\text { length }\end{array}$ & $\begin{array}{c}\text { Ear } \\
\text { diameter }\end{array}$ & $\begin{array}{l}\text { No. of kernel } \\
\text { rows }\end{array}$ & $\begin{array}{l}\text { Ears fresh } \\
\text { weight }\end{array}$ & $\begin{array}{c}\text { Kernel } \\
\text { yield }\end{array}$ & WUE \\
\hline Block & 2 & 4.962 & 0.120 & 0.050 & 19.05 & 121.62 & 2419 & 240 \\
\hline Cultivars (C) & 2 & $39.42^{*}$ & $26.65^{*}$ & $0.321^{*}$ & 0.500 & $19135^{*}$ & $1019^{*}$ & $99.8^{*}$ \\
\hline Error main plot & 4 & 0.157 & 0.001 & 0.005 & $1.055^{*}$ & 207.69 & 1432 & 142 \\
\hline Establishment (E) & 1 & $1350^{*}$ & $31.28^{*}$ & $0.735^{*}$ & 0.907 & $2971.8^{*}$ & $9826^{*}$ & $981^{*}$ \\
\hline $\mathrm{C} \times \mathrm{E}$ & 2 & $10.16^{*}$ & $9.601^{*}$ & $0.043^{*}$ & 0.129 & 52.702 & $1707^{*}$ & $169^{*}$ \\
\hline Error split plot & 6 & 0.277 & 0.001 & 0.038 & 0.166 & 192.15 & 1139 & 112 \\
\hline Fertilizer (F) & 2 & $80.57^{*}$ & $5.040^{*}$ & $1.107^{*}$ & $22.38^{*}$ & $3428.8^{*}$ & $6474^{*}$ & $646^{*}$ \\
\hline $\mathrm{C} \times \mathrm{F}$ & 4 & $1.018^{*}$ & $0.327^{*}$ & $0.062^{*}$ & 0.222 & 299.56 & $7935^{*}$ & $792^{*}$ \\
\hline $\mathrm{E} \times \mathrm{F}$ & 2 & $0.500^{*}$ & $0.107^{*}$ & $0.127^{*}$ & 0.574 & 313.72 & $1386^{*}$ & $137^{*}$ \\
\hline $\mathrm{C} \times \mathrm{E} \times \mathrm{F}$ & 4 & $3.333^{*}$ & $0.622^{*}$ & $0.021^{*}$ & 0.296 & 227.13 & $6256^{*}$ & $624^{*}$ \\
\hline Error split-split plot & 24 & 0.129 & 0.001 & 0.006 & 0.333 & 185.10 & 3084 & 307 \\
\hline Corrected Total & 53 & & & & & & & \\
\hline
\end{tabular}

$\mathrm{ns}=$ not significant or $*$ * significant at $\mathrm{p}<0.05$, ANOVA. / ns $=$ no significativo o $*$ significativo a $\mathrm{p}<0,05$, ANOVA.

Table 2. Impacts of three sweet corn (Zea mays) cultivars, establishment methods, and boron fertilizer on time to maturity, the length and diameter of ears, kernel ears rows number, fresh weight, kernel products, and water use (WUE) in sweet corn. Research Station of Horticulture Department and Landscape Gardening Architecture, University of Diyala, Baqubah, Iraq, from 19 March to June 2020.

Cuadro 2. Efecto de tres cultivares de maíz dulce (Zea mays), métodos de establecimiento y fertillización con boro, sobre el tiempo de maduración, la longitud y el diámetro de las mazorcas, el número de filas de granos de las mazorcas, el peso fresco, la producción de grano y el uso del agua (WUE) en el maíz dulce. Research Station of Horticulture Department and Landscape Gardening Architecture, University of Diyala, Baqubah, Iraq, 19 de marzo al 20 de junio de 2020.

\begin{tabular}{|c|c|c|c|c|c|c|c|}
\hline \multicolumn{8}{|l|}{ Factors } \\
\hline Cultivars & $\begin{array}{c}\text { Early of } \\
\text { maturity (day) }\end{array}$ & $\begin{array}{l}\text { Ear length } \\
\text { (cm) }\end{array}$ & $\begin{array}{c}\text { Ear diameter } \\
(\mathrm{cm})\end{array}$ & $\begin{array}{c}\text { No. of kernel } \\
\text { rows }\end{array}$ & $\begin{array}{l}\text { Ears fresh } \\
\text { weight (g) }\end{array}$ & $\begin{array}{c}\text { Kernel yield } \\
\left(\mathbf{t ~ h a}^{-1}\right)\end{array}$ & $\begin{array}{c}\text { WUE } \\
\left(\mathrm{kg} \mathrm{m}^{-3}\right)\end{array}$ \\
\hline Roi Soleal & $60.27^{\mathrm{c}}$ & $16.85^{\mathrm{b}}$ & $4.26^{\mathrm{c}}$ & $15.66^{\mathrm{c}}$ & $226^{\mathrm{b}}$ & $4.67^{\mathrm{c}}$ & $2.22^{\mathrm{c}}$ \\
\hline Seker Misir & $57.50^{\mathrm{a}}$ & $16.11^{\mathrm{c}}$ & $4.53^{\mathrm{a}}$ & $16.00^{\mathrm{a}}$ & $187^{\mathrm{c}}$ & $6.00^{\mathrm{a}}$ & $2.85^{\mathrm{a}}$ \\
\hline Succar & $59.77^{\mathrm{c}}$ & $18.48^{\mathrm{a}}$ & $4.41^{\mathrm{b}}$ & $15.83^{\mathrm{b}}$ & $251^{\mathrm{a}}$ & $4.74^{b}$ & $2.25^{\mathrm{b}}$ \\
\hline \multicolumn{8}{|l|}{$\begin{array}{l}\text { Establishment } \\
\text { Methods }\end{array}$} \\
\hline Direct Sowing & $64.18^{\mathrm{b}}$ & $16.38^{\mathrm{b}}$ & $4.28^{\mathrm{b}}$ & $15.70^{\mathrm{b}}$ & $214^{\mathrm{b}}$ & $4.71^{\mathrm{b}}$ & $2.24^{\mathrm{b}}$ \\
\hline Transplanting & $54.18^{\mathrm{a}}$ & $17.91^{\mathrm{a}}$ & $4.52^{\mathrm{a}}$ & $15.96^{\mathrm{a}}$ & $229^{a}$ & $5.56^{\mathrm{a}}$ & $2.64^{\mathrm{a}}$ \\
\hline \multicolumn{8}{|l|}{ Fertilizer $\mathrm{mg} \mathrm{L}^{-1}$} \\
\hline 0 & $61.61^{\mathrm{c}}$ & $16.56^{\mathrm{c}}$ & $4.12^{\mathrm{c}}$ & $14.55^{\mathrm{c}}$ & $206^{c}$ & $4.48^{c}$ & $2.13^{c}$ \\
\hline 50 & $58.22^{\mathrm{b}}$ & $17.61^{\mathrm{a}}$ & $4.58^{\mathrm{a}}$ & $16.61^{\mathrm{a}}$ & $227^{\mathrm{b}}$ & $5.64^{\mathrm{a}}$ & $2.68^{\mathrm{a}}$ \\
\hline 75 & $57.72^{\mathrm{a}}$ & $17.26^{\mathrm{b}}$ & $4.51^{\mathrm{b}}$ & $16.33^{\mathrm{b}}$ & $232^{\mathrm{a}}$ & $5.29^{\mathrm{b}}$ & $2.51^{\mathrm{b}}$ \\
\hline
\end{tabular}

Data in interaction analyzed with Least Squares means and means separated with Tukey. / Los datos en interacción analizados con las medias de mínimos cuadrados y las medias separadas con Tukey.

Values in groups in columns followed by the same letter are not significantly different, $\mathrm{p}<0.05$. / Los valores en grupos en columnas seguidas por la misma letra no son significativamente diferentes, $\mathrm{p}<0,05$. 
The cultivars and establishment methods, cultivars and foliar application of boron, establishment methods and foliar application of boron, interactions significantly affected on all measured variables (Table 3). The cv. Seker Misir with the transplanting method resulted in the less time to maturity, widest ears, a greater number of kernel rows, most kernel yield, and higher WUE. The tallest ears and heaviest fresh ears were produced on Succar with the same establishment methods (Transplanting). Kernel productivity and WUE were improved due to the use of 50

Table 3. Means comparison, the interactions effects of cultivar $\times$ establishment methods, cultivar $\times$ fertilizer and establishment methods $\times$ fertilizer on time to maturity, length and diameter of ears, kernel rows number, ears fresh weight, kernel productivity, and water use (WUE) in sweet corn (Zea mays). Research Station of Horticulture Department and Landscape Gardening Architecture, University of Diyala, Baqubah, Iraq, from 19 March to June 2020.

Cuadro 3. Comparación de medias, efectos de las interacciones entre el cultivar $\times$ métodos de establecimiento, cultivar $\times$ fertilizante y los métodos de establecimiento $\times$ fertilizante, sobre el tiempo de maduración, la longitud y el diámetro de las espigas, el número de hileras de granos, el peso fresco de las mazorcas, la productividad de grano y el uso del agua (WUE) en el maíz dulce (Zea mays). Research Station of Horticulture Department and Landscape Gardening Architecture, University of Diyala, Baqubah, Iraq, 19 de marzo al 20 de junio de 2020 .

\begin{tabular}{|c|c|c|c|c|c|c|c|c|}
\hline \multicolumn{2}{|c|}{ Factors } & \multirow{2}{*}{$\begin{array}{c}\text { Early of } \\
\text { maturity } \\
\text { (day) }\end{array}$} & \multirow{2}{*}{$\begin{array}{c}\text { Ear } \\
\text { length } \\
(\mathbf{c m})\end{array}$} & \multirow{2}{*}{$\begin{array}{c}\text { Ear } \\
\text { diameter } \\
(\mathbf{c m})\end{array}$} & \multirow{2}{*}{$\begin{array}{c}\text { No. of } \\
\text { kernel } \\
\text { rows }\end{array}$} & \multirow{2}{*}{$\begin{array}{l}\text { Ears fresh } \\
\text { weight } \\
\text { (g) }\end{array}$} & \multirow{2}{*}{$\begin{array}{c}\text { Kernel } \\
\text { yield } \\
(\mathbf{t ~ h a - 1 )}\end{array}$} & \multirow{2}{*}{$\begin{array}{c}\text { WUE } \\
\left(\mathrm{kg} \mathrm{m}^{-3}\right)\end{array}$} \\
\hline Cultivars & Establishment & & & & & & & \\
\hline \multirow[t]{2}{*}{ Roi Soleal } & Direct sowing & $66.00^{\mathrm{d}}$ & $15.27^{\mathrm{f}}$ & $4.11^{\mathrm{c}}$ & $15.55^{\mathrm{b}}$ & $218^{\mathrm{c}}$ & $3.89^{\mathrm{e}}$ & $1.85^{\mathrm{e}}$ \\
\hline & Transplanting & $54.55^{\mathrm{b}}$ & $18.42^{\mathrm{b}}$ & $4.42^{\mathrm{b}}$ & $15.77^{\mathrm{b}}$ & $234^{\mathrm{b}}$ & $5.44^{\mathrm{b}}$ & $2.59^{\mathrm{b}}$ \\
\hline \multirow[t]{2}{*}{ Seker Misir } & Direct sowing & $62.55^{\mathrm{c}}$ & $15.55^{\mathrm{e}}$ & $4.40^{\mathrm{b}}$ & $15.77^{\mathrm{b}}$ & $181^{\mathrm{d}}$ & $5.70^{\mathrm{b}}$ & $2.59^{\mathrm{b}}$ \\
\hline & Transplanting & $52.44^{\mathrm{a}}$ & $16.66^{\mathrm{d}}$ & $4.66^{\mathrm{a}}$ & $16.22^{\mathrm{a}}$ & $192^{\mathrm{d}}$ & $6.31^{\mathrm{a}}$ & $3.00^{\mathrm{a}}$ \\
\hline \multirow[t]{2}{*}{ Succar } & Direct sowing & $64.00^{\text {cd }}$ & $18.32^{\mathrm{c}}$ & $4.35^{\mathrm{b}}$ & $15.77^{\mathrm{b}}$ & $243^{b}$ & $4.54^{\mathrm{d}}$ & $2.16^{\mathrm{d}}$ \\
\hline & Transplanting & $55.55^{\mathrm{b}}$ & $18.64^{\mathrm{a}}$ & $4.47^{\mathrm{b}}$ & $15.88^{\mathrm{b}}$ & $260^{\mathrm{a}}$ & $4.94^{c}$ & $2.32^{\mathrm{c}}$ \\
\hline Cultivars & Fertilizer mg $\mathbf{L}^{-1}$ & & & & & & & \\
\hline \multirow[t]{3}{*}{ Roi Soleal } & 0 & $63.00^{\mathrm{f}}$ & $16.08^{\mathrm{g}}$ & $3.85^{\mathrm{g}}$ & $14.33^{\mathrm{b}}$ & $204^{c}$ & $3.62^{\mathrm{f}}$ & $1.72^{\mathrm{f}}$ \\
\hline & 50 & $59.50^{c}$ & $17.66^{\mathrm{c}}$ & $3.53^{\mathrm{bc}}$ & $16.66^{\mathrm{a}}$ & $237^{\mathrm{b}}$ & $5.45^{\mathrm{c}}$ & $2.59^{\mathrm{c}}$ \\
\hline & 75 & $58.66^{\mathrm{b}}$ & $16.96^{\mathrm{d}}$ & $4.41^{\mathrm{d}}$ & $16.00^{\mathrm{a}}$ & $237^{\mathrm{b}}$ & $4.93^{\mathrm{d}}$ & $2.34^{\mathrm{d}}$ \\
\hline \multirow[t]{3}{*}{ Seker Misir } & 0 & $60.00^{\mathrm{d}}$ & $15.50^{\mathrm{h}}$ & $4.31^{\mathrm{e}}$ & $14.66^{\mathrm{b}}$ & $172^{\mathrm{d}}$ & $5.30^{\mathrm{c}}$ & $2.52^{\mathrm{c}}$ \\
\hline & 50 & $56.33^{\mathrm{a}}$ & $16.66^{\mathrm{e}}$ & $4.66^{\mathrm{a}}$ & $16.66^{\mathrm{a}}$ & $195^{\mathrm{c}}$ & $6.52^{\mathrm{a}}$ & $3.10^{\mathrm{a}}$ \\
\hline & 75 & $56.16^{\mathrm{a}}$ & $16.16^{f}$ & $4.61^{\mathrm{ab}}$ & $16.66^{\mathrm{a}}$ & $194^{c}$ & $6.20^{\mathrm{b}}$ & $2.95^{\mathrm{b}}$ \\
\hline \multirow[t]{3}{*}{ Succar } & 0 & $61.83^{\mathrm{e}}$ & $18.13^{\mathrm{b}}$ & $4.20^{\mathrm{f}}$ & $14.66^{\mathrm{b}}$ & $241^{\mathrm{b}}$ & $4.51^{\mathrm{e}}$ & $2.14^{\mathrm{e}}$ \\
\hline & 50 & $58.83^{\mathrm{b}}$ & $18.66^{\mathrm{a}}$ & $4.55^{\mathrm{bc}}$ & $16.50^{\mathrm{a}}$ & $248^{\mathrm{ab}}$ & $4.96^{\mathrm{d}}$ & $2.36^{\mathrm{d}}$ \\
\hline & 75 & $58.66^{\mathrm{b}}$ & $18.66^{\mathrm{a}}$ & $4.50^{\mathrm{cd}}$ & $16.33^{\mathrm{a}}$ & $265^{\mathrm{a}}$ & $4.75^{\mathrm{d}}$ & $2.26^{\mathrm{d}}$ \\
\hline Establishment & Fertilizer $\mathbf{m g ~} \mathbf{L}^{-1}$ & & & & & & & \\
\hline \multirow[t]{3}{*}{ Direct Sowing } & 0 & $66.77^{\mathrm{d}}$ & $15.72^{\mathrm{f}}$ & $3.91^{\mathrm{e}}$ & $14.22^{\mathrm{c}}$ & $195^{\mathrm{c}}$ & $4.13^{\mathrm{e}}$ & $1.96^{\mathrm{e}}$ \\
\hline & 50 & $63.22^{\mathrm{c}}$ & $16.88^{\mathrm{d}}$ & $4.53^{\mathrm{b}}$ & $16.55^{\mathrm{a}}$ & $224^{\mathrm{b}}$ & $5.23^{\mathrm{c}}$ & $2.49^{\mathrm{c}}$ \\
\hline & 75 & $62.55^{\mathrm{c}}$ & $16.55^{\mathrm{e}}$ & $4.42^{\mathrm{c}}$ & $16.33^{\mathrm{a}}$ & $223^{b}$ & $4.77^{\mathrm{d}}$ & $2.27^{\mathrm{d}}$ \\
\hline \multirow[t]{3}{*}{ Transplanting } & 0 & $56.44^{\mathrm{b}}$ & $17.42^{\mathrm{b}}$ & $3.33^{\mathrm{d}}$ & $14.88^{\mathrm{b}}$ & $217^{\mathrm{b}}$ & $4.82^{\mathrm{d}}$ & $2.29^{\mathrm{d}}$ \\
\hline & 50 & $53.22^{\mathrm{ab}}$ & $18.33^{\mathrm{a}}$ & $4.63^{\mathrm{a}}$ & $16.66^{\mathrm{a}}$ & $230^{\mathrm{ab}}$ & $6.06^{\mathrm{a}}$ & $2.88^{\mathrm{a}}$ \\
\hline & 75 & $52.88^{\mathrm{a}}$ & $17.97^{\mathrm{ab}}$ & $4.60^{\mathrm{ab}}$ & $16.33^{\mathrm{a}}$ & $240^{\mathrm{a}}$ & $5.81^{\mathrm{a}}$ & $2.76^{\mathrm{a}}$ \\
\hline
\end{tabular}

Data in the interaction were analyzed with the Least Squares Means and the means separated with minimun significant difference. / Datos en la interacción se analizaron con las medias de mínimos cuadrados y las medias separadas con diferencia mínima significativa. 
$\mathrm{mg} \mathrm{L}^{-1}$ boron for Seker Misir cv. The lowest of time to maturity and widest ears were produced for the same cv. use of 50 or $75 \mathrm{mg} \mathrm{L}^{-1}$ boron. For Succar cv., use of 50 or $75 \mathrm{mg} \mathrm{L}^{-1}$ boron produced the tallest ears and heaviest fresh ears. For all cvs., the use of boron dose produced a greater number of kernel rows. For the transplanting method use of 50 or $75 \mathrm{mg} \mathrm{L}^{-1}$ boron resulted in the lowest time to maturity, tallest ears, widest ears, a greater number of kernel rows, most kernel productivity, and WUE. The heaviest fresh ears were produced for all cvs. use of boron dose.

In all the cultivars and establishment methods, the early of maturity, length and diameter ears, kernel rows number, ears fresh weight, total kernel yield, and WUE, significantly increased with the foliar application of boron dose (Table 4). Early in maturity and ear diameter was generally the best in each combination for the 50 or 75 $\mathrm{mg} \mathrm{L}^{-1}$ boron dose for Seker Misir cv. with transplanting. For this interaction, a greater number of Kernel rows were generally highest for the 50 or $75 \mathrm{mg} \mathrm{L}^{-1}$ boron dose regardless of cultivar or establishment method. kernel productivity and WUE were generally the best in each combination for each the 50 or $75 \mathrm{mg} \mathrm{L}^{-1}$ boron dose Seker

Table 4. Means comparison of the interaction of the impacts of cultivar, establishment methods, and fertilizer on time to maturity, length and diameter of ears, kernel rows number, ears fresh weight, kernel productivity, and water use (WUE) in sweet corn (Zea mays). Research Station of Horticulture Department and Landscape Gardening Architecture, University of Diyala, Baqubah, Iraq, from 19 March to June 2020.

Cuadro 4. Comparación de medias la interacción de los impactos del cultivar, los métodos de establecimiento y el fertilizante, sobre el tiempo de maduración, la longitud y el diámetro de las mazorcas, el número de filas de granos de las mazorcas, el peso fresco de las mazorcas, la productividad de grano y el uso del agua (WUE) en el maíz dulce (Zea mays). Research Station of Horticulture Department and Landscape Gardening Architecture, University of Diyala, Baqubah, Iraq, 19 de marzo al 20 de junio de 2020.

\begin{tabular}{|c|c|c|c|c|c|c|c|c|c|}
\hline \multicolumn{3}{|c|}{ Factors } & \multirow{2}{*}{$\begin{array}{l}\text { Early of } \\
\text { maturity } \\
\text { (day) }\end{array}$} & \multirow{2}{*}{$\begin{array}{l}\text { Ear } \\
\text { length } \\
(\mathrm{cm})\end{array}$} & \multirow{2}{*}{$\begin{array}{c}\text { Ear } \\
\text { diameter } \\
(\mathbf{c m})\end{array}$} & \multirow{2}{*}{$\begin{array}{c}\text { No. of } \\
\text { kernel } \\
\text { rows }\end{array}$} & \multirow{2}{*}{$\begin{array}{l}\text { Ears fresh } \\
\text { weight } \\
\text { (g) }\end{array}$} & \multirow{2}{*}{$\begin{array}{c}\text { Kernel } \\
\text { yield } \\
\left(\mathbf{t ~ h a}^{-1}\right)\end{array}$} & \multirow{2}{*}{$\begin{array}{c}\text { WUE } \\
\left(\mathrm{kg} \mathrm{m}^{-3}\right)\end{array}$} \\
\hline Cultivars & Establishment & $\begin{array}{c}\text { Fertilizer } \\
\left(\mathrm{mg} \mathrm{L}^{-1}\right)\end{array}$ & & & & & & & \\
\hline \multirow{6}{*}{ Roi Soleal } & Direct Sowing & 0 & $69.66^{g}$ & $14.83^{j}$ & $3.53^{\mathrm{g}}$ & $14.00^{\mathrm{d}}$ & $195^{\text {fg }}$ & $3.33^{\mathrm{h}}$ & $1.58^{\mathrm{h}}$ \\
\hline & & 50 & $65.00^{\mathrm{f}}$ & $15.66^{\mathrm{h}}$ & $4.50^{\mathrm{c}}$ & $16.66^{\mathrm{a}}$ & $229^{\text {cde }}$ & $4.49^{\mathrm{ef}}$ & $2.13^{\mathrm{ef}}$ \\
\hline & & 75 & $63.33^{\mathrm{e}}$ & $15.33^{\mathrm{i}}$ & $4.30^{\mathrm{de}}$ & $16.00^{\mathrm{ab}}$ & $229^{\text {cde }}$ & $3.86^{\mathrm{g}}$ & $1.84^{\mathrm{g}}$ \\
\hline & Transplanting & 0 & $56.33^{\mathrm{c}}$ & $17.33^{\mathrm{d}}$ & $4.16^{\mathrm{ef}}$ & $14.66^{\mathrm{cd}}$ & $213^{\text {ef }}$ & $3.92^{\mathrm{g}}$ & $1.86^{\mathrm{g}}$ \\
\hline & & 50 & $54.00^{\mathrm{b}}$ & $19.33^{\mathrm{a}}$ & $4.56^{\mathrm{bc}}$ & $16.66^{\mathrm{a}}$ & $245^{\text {bcd }}$ & $6.42^{\mathrm{a}}$ & $3.05^{\mathrm{a}}$ \\
\hline & & 75 & $53.33^{\mathrm{b}}$ & $18.60^{\mathrm{b}}$ & $4.53^{\mathrm{c}}$ & $16.00^{\mathrm{ab}}$ & $245^{\text {bcd }}$ & $5.99^{\mathrm{b}}$ & $2.85^{\mathrm{b}}$ \\
\hline \multirow{6}{*}{$\begin{array}{l}\text { Seker } \\
\text { Misir }\end{array}$} & Direct Sowing & 0 & $65.33^{f}$ & $14.66^{\mathrm{k}}$ & $4.10^{\mathrm{f}}$ & $14.00^{\mathrm{d}}$ & $165^{\mathrm{h}}$ & $4.73^{\mathrm{de}}$ & $2.25^{\mathrm{de}}$ \\
\hline & & 50 & $61.33^{\mathrm{d}}$ & $16.33^{\mathrm{g}}$ & $4.56^{\mathrm{bc}}$ & $16.66^{\mathrm{a}}$ & $190^{\mathrm{fg}}$ & $6.40^{\mathrm{a}}$ & $3.04^{\mathrm{a}}$ \\
\hline & & 75 & $61.00^{\mathrm{d}}$ & $15.66^{\mathrm{h}}$ & $4.53^{\mathrm{c}}$ & $16.66^{\mathrm{a}}$ & $189^{\mathrm{fg}}$ & $5.98^{\mathrm{b}}$ & $2.84^{\mathrm{b}}$ \\
\hline & Transplanting & 0 & $54.66^{\mathrm{b}}$ & $16.33^{\mathrm{g}}$ & $4.53^{\mathrm{c}}$ & $15.33^{\mathrm{bc}}$ & $179^{\text {gh }}$ & $5.87^{\mathrm{b}}$ & $2.79^{b}$ \\
\hline & & 50 & $51.33^{\mathrm{a}}$ & $17.00^{\mathrm{e}}$ & $4.76^{\mathrm{a}}$ & $16.66^{\mathrm{a}}$ & $199^{\mathrm{fg}}$ & $6.64^{\mathrm{a}}$ & $3.16^{\mathrm{a}}$ \\
\hline & & 75 & $51.33^{\mathrm{a}}$ & $16.66^{\mathrm{f}}$ & $4.70^{\mathrm{ab}}$ & $16.66^{\mathrm{a}}$ & $198^{\mathrm{fg}}$ & $6.42^{\mathrm{a}}$ & $3.05^{\mathrm{a}}$ \\
\hline \multirow{6}{*}{ Succar } & Direct Sowing & 0 & $65.33^{f}$ & $17.66^{\mathrm{c}}$ & $4.10^{\mathrm{f}}$ & $14.66^{\mathrm{cd}}$ & $224^{\mathrm{de}}$ & $4.35^{\mathrm{f}}$ & $2.07^{\mathrm{f}}$ \\
\hline & & 50 & $63.33^{\mathrm{e}}$ & $18.66^{\mathrm{b}}$ & $4.53^{\mathrm{c}}$ & $16.33^{\mathrm{ab}}$ & $253^{\mathrm{abc}}$ & $4.79^{\mathrm{de}}$ & $2.28^{\mathrm{de}}$ \\
\hline & & 75 & $63.33^{\mathrm{e}}$ & $18.66^{\mathrm{b}}$ & $4.43^{\mathrm{cd}}$ & $16.33^{\mathrm{ab}}$ & $253^{\mathrm{abc}}$ & $4.48^{\mathrm{ef}}$ & $2.13^{\mathrm{ef}}$ \\
\hline & Transplanting & 0 & $58.33^{\mathrm{c}}$ & $18.60^{\mathrm{b}}$ & $4.30^{\mathrm{de}}$ & $14.66^{\mathrm{cd}}$ & $259^{\mathrm{ab}}$ & $4.67^{\mathrm{ef}}$ & $2.22^{\mathrm{ef}}$ \\
\hline & & 50 & $54.33^{\mathrm{b}}$ & $18.66^{\mathrm{b}}$ & $4.56^{\mathrm{bc}}$ & $16.66^{\mathrm{a}}$ & $244^{\mathrm{bcd}}$ & $5.13^{c}$ & $2.44^{\mathrm{c}}$ \\
\hline & & 75 & $54.00^{\mathrm{b}}$ & $18.66^{\mathrm{b}}$ & $4.56^{\mathrm{bc}}$ & $16.33^{\mathrm{ab}}$ & $276^{\mathrm{a}}$ & $5.02^{\mathrm{cd}}$ & $2.39^{\mathrm{cd}}$ \\
\hline
\end{tabular}

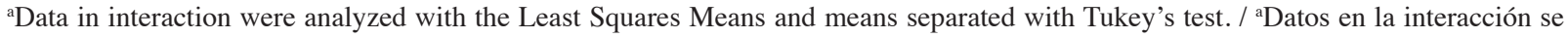
analizaron con medias de mínimos cuadrados y medias separadas con la prueba de Tukey.

${ }^{b}$ Values in the columns followed by the same letter were not significantly different, $\mathrm{p}<0.05$. ${ }^{\mathrm{b}}$ Valores en las columnas seguidos con la misma letra no fueron significativamente diferentes, $\mathrm{p}<0,05$. 
Misir or Roi Soleal with transplanting method. For this interaction, the ear length was generally highest for the 50 $\mathrm{mg} \mathrm{L}^{-1}$ boron dose in Roi Soleal cv. with the transplanting method.

\section{Discussion}

The study revealed significant genotypic variances for yield and its components characters. This might be attributed to the genotypic variation between the three sweet corn cultivars (genetic factors, intrinsic to the cultivar), being little affected by environmental factors (Krichevsky et al., 2007; Stansluos et al., 2020; Williams, 2010; Williams \& Pataky, 2012). Genotype and management interaction was also found to be significant for most of the characters. The study indicated influence of both genotype and environment in expression of these characters.

Transplanting sweet corn was investigated as a method to improve stand establishment and hasten maturity. Transplanting sweet corn has been reported to produce significantly higher emergence percentage than direct seeded (Welbaum et al., 2001) and significantly reduced days required for emergence comparing to direct seeded (Dale \& Drennan, 1997). It is obvious from the obtained results that the average days to maturity, length and diameter of ear, number of kernel rows, ears fresh weight, kernel yield and WUE was improved in the transplanting experiment compared to when seeds were directly cultivated in the field. This may be justified by the numerous benefits of transplanting.

The positive effect of boron on Kernel yield of sweet corn may be due to improvements in the physiological processes of plants. The presence of boron is responsible for correct pollination and filling of the cobs with grain. Also, the presence of B in maize strengthens the stiffness of the stems, which reduces lodging and protects plants from pests. Insufficient boron content within plants causes the inhibition of chlorophyll synthesis.

\section{Conclusions}

Based on obtained results, it can be concluded that, transplanting method can double yield the linear growth of agro-morphological traits, increased kernel yield and WUE as compared to direct sowing as stand-alone innovations. Alternate sweet corn establishment methods like transplanting can help in establishing a sweet corn crop earlier than a conventional transplanted crop (direct sowing). In regard to cultivars performance, Seker Misir outperformed Roi Soleal and Succar in days to maturity, kernel rows number, kernel yield and WUE among the transplanting method and application of boron $\left(50\right.$ or $\left.75 \mathrm{ml} \mathrm{L}^{-1}\right)$ practices.

Generally from this study the results show that the cv. Seker Misir were best in its most tested characters (ear diameter, kernel rows number, Kernel yield and WUE) over the other cultivars.

It is concluded that the mean values obtained against boron dose application were potential contributor to total grain mass by improving the days to maturity, length and diameter ear, number of kernel rows, ears fresh weight, kernel yield and WUE. Foliar boron application $\left(75 \mathrm{ml} \mathrm{L}^{-1}\right)$ gave the highest recorded values for all studied trades.

The boron dose foliar application (50 and $75 \mathrm{mg} \mathrm{L}^{-1}$ ) and transplanting method improved the yield, yield components, and water use efficiency of sweet corn, regardless of the cultivars.

\section{References}

Abdel-Motagally, F. M. F., \& El-Zohri, M. (2018). Improvement of wheat yield grown under drought stress by boron foliar application at different growth stages. Journal of the Saudi Society of Agricultural Sciences, 17(2), 178-185. https:// doi.org/10.1016/j.jssas.2016.03.005

Agron. Mesoam. 33(1): Artículo 45633, 2022 ISSN 2215-3608 doi:10.15517/am.v33i1.45633 
Ahmad, W., Zia, M. H., Malhi, S. S., \& Niaz and Saifullah, A. (2014). Boron deficiency in soils and crops: A review. In A. Goyal (Ed.), Crop plant (Chapter 5. pp. 77-117). IntechOpen. https://www.intechopen.com/chapters/35614

Barbosa, J. C., \& Maldonado, J. W. (2015). Experimentação Agronômica \& AgroEstat: Sistema para Análises Estatísticas de Ensaios Agronômicos. Multipress.

Black, C. A. (Ed.) (1965). Methods of soil analysis. Part 1. Physical and mineralogical properties including statistics of measurement and sampling, 9.1. American Society of Agronomy, Inc. https://doi.org/10.2134/agronmonogr9.1.

Camacho-Cristóbal, J. J., Rexach, J., \& González-Fontes, A. (2008). Boron in plants: Deficiency and toxicity. Journal of Integrative Plant Biology, 50(10), 1247-1255. https://doi.org/10.1111/j.1744-7909.2008.00742.x

Céccoli, G., Ortega, L. I., Gariglio, N. F., Favaro, J. C., \& Bouzo, C. A. (2014). Sweet corn (Zea mays L.) growth and yield are influenced by establishment methods. Bothalia Journal, 44(6), 2-12.

Dale, A. E., \& Drennan, D. S. H. (1997). Transplanted maize (Zea mays) for grain production in southern England. I. Effects of planting date, transplant age at planting and cultivar on grain yield. Journal of Agricultural Science, 128(1), 27-35. https://doi.org/10.1017/S0021859696003875

Fagan, E. B., Ono, E. O., Rodrigues, J. D., Soares, L. H., \& Neto, D. (2016). Plant physiology: Metabolism and mineral nutrition. Andrei.

Fanadzo, M., Chiduza, C., \& Mnkeni, P. N. S. (2009). Comparative response of direct-seeded and transplanted maize (Zea mays L.) to nitrogen fertilization at Zanyokwe irrigation scheme, Eastern Cape, South Africa. African Journal of Agricultural Research, 4(8), 689-694.

Fayaz, S., Teeli, N. A., Hussain, A., Ganai, M. A., Mir, S. A., Zahoor, A., \& Baba, Z. A. (2019). Response of sweet corn hybrid to establishment methods and weed management practices under temperate conditions. International Journal of Current Microbiology and Applied Sciences, 8(2), 1301-1309. https://doi.org/10.20546/ijcmas.2019.802.152

Grubinger, V. (2014). Transplanting sweet corn. The University of Vermont. https://www.uvm.edu/vtvegandberry/factsheets/ transplantingsweetcorn.html

Günes, A., Ataoğlu, N., Esringü, A., Uzun, O., Ata, S., \& Turan, M. (2011). Yield and chemical composition of corn (Zea mays L.) as affected by boron management. International Journal of Plant, Animal and Environmental Sciences, 1(1), 42-53. http://ijpaes.com/admin/php/uploads/93_pdf.pdf

Gupta, U. C. (1993). Boron and its role in crop production. CRC Press.

Kaur, G., \& Nelson, K. A. (2015). Effect of foliar boron fertilization of fine textured soils on corn yields. Agronomy, 5(1), 1-18. https://doi.org/10.3390/agronomy5010001

Krichevsky, A., Kozlovsky, S. V., Tian, G. -W., Chen, M. -H., Zaltsman, A., \& Citovsky, V. (2007). How pollen tubes grow. Developmental Biology, 303(2), 405-420. https://doi.org/10.1016/j.ydbio.2006.12.003

Lordkaew, S., Dell, B., Jamjod, S., Jamjod, S., \& Rerkasem, B. (2011). Boron deficiency in maize. Plant and Soil, 342(1-2), 207-220. https://doi.org/10.1007/s11104-010-0685-7

Marschner, H., \& Rimmington, G. (1996). Mineral nutrition of higher plants. Academic Press.

Mengel, K., Kirby, E. A., Kosegarden, H., \& Appel, T. (Eds.) (2001). Principles of plant nutrition (5 ${ }^{\text {th }}$ Ed.). Springer Science + Business Media, B. V. https://doi.org/10.1007/978-94-010-1009-2

Agron. Mesoam. 33(1): Artículo 45633, 2022

ISSN 2215-3608 doi:10.15517/am.v33i1.45633 
Pilbeam, D. J., \& Kirkby, E. A. (1983). The physiological role of boron in plants. Journal of Plant Nutrition, 6(7), 563-582. https://doi.org/10.1080/01904168309363126

Sánchez Andonova, P., Rattin, J., \& Di Benedetto, A. (2014). Yield increase as influenced by transplanting of sweet maize (Zea mays L. saccharata). American Journal of Experimental Agriculture, 4(11), 1314-1329. https://doi.org/10.9734/ AJEA/2014/11077

Srdić, J., Pajić, Z., \& Filipović, M. (2016). Sweet corn (Zea mays L.) fresh ear yield independence of genotype and the environment. Selekcija I semenarstvo, 22(1), 27-33. https://doi.org/10.5937/SelSem1601027S

Stansluos, A. A. L., Öztürk, A., \& Kodaz, S. (2020). Agronomic performance of different sweet corn cultivars in the highest plain of Turkey: Plant growth and yields. IOSR Journal of Agriculture and Veterinary Science, 13(1), 13-22.

Tampus, D. S., \& Escasinas, R. O. (2019). Effects of swiftlet (Aerodramus fuciphagus) manure and methods of crop establishment on the growth and yield of sweet corn (Zea mays var. Saccharata) in Western Leyte, Philippines. Advances in Crop Science and Technology, 7(2), 1-7.

Tracy, W. (2001). Specialty corn. In A. R. Hallauer (Eds.), Specialty corns (2 ${ }^{\text {nd }}$ Ed.) (p. 162- 204). CRC Press.

Ugur, A., \& Maden, H. A. (2015). Sowing and planting period on yield and ear quality of sweet corn (Zea mays L. var. saccharata). Ciência e Agrotecnologia, 39(1), 48-57. https://doi.org/10.1590/S1413-70542015000100006

Wang, Y., Li, X., Yaying, L., Jifu, L., Guobin, X., Wei, Z., Fusheng, Y., Yanhong, L., Yulin, L., \& Jianwei, L. (2012). Responses of direct-seeding rapeseed to fertilization in fields of red soil different in fertility. Acta Pedologica Sinica, 49(1), 121-129. https://doi.org/10.11766/trxb201105300195

Welbaum, G. E., Frantz, J. M., Gunatilaka, M. K., \& Shen, Z. (2001). A Comparison of the growth, establishment, and maturity of direct-seeded and transplanted sh2 sweet corn. HortScience, 36(4), 687-690. https://doi.org/10.21273/ HORTSCI.36.4.687

Williams, M. M. (2010). Biological significance of low weed population densities on sweet corn. Agronomy Journal, 102(2), 464-468. https://doi.org/10.2134/agronj2009.0308

Williams, M. M., \& Pataky, J. K. (2012). Interactions between maize dwarf mosaic and weed interference on sweet corn. Field Crops Research, 128, 48-54. https://doi.org/10.1016/j.fcr.2011.12.005

Zoz, T., Steiner, F., Seidel, E. P., Castagnara, D. D., \& de Souza, G. E. (2016). Foliar application of calcium and boron improves the spike fertile and yield of wheat. Bioscience Journal, Uberlândia, 32(4), 873-880. https://doi.org/10.14393/BJv32n4a2016-29714

Agron. Mesoam. 33(1): Artículo 45633, 2022 ISSN 2215-3608 doi:10.15517/am.v33i1.45633 